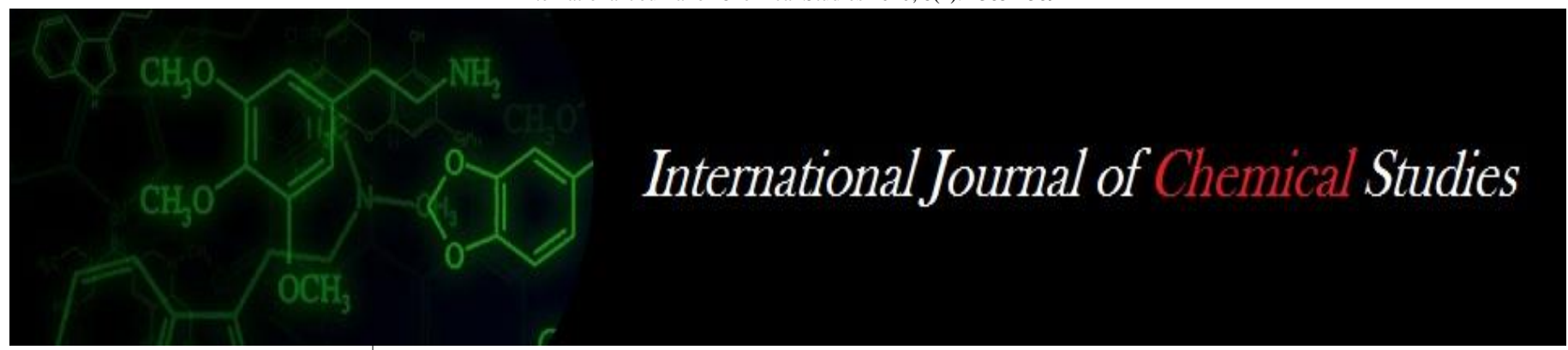

P-ISSN: 2349-8528

E-ISSN: 2321-4902

www.chemijournal.com

IJCS 2020; 8(2): 2385-2389

(C) 2020 IJCS

Received: 15-01-2020

Accepted: 19-02-2020

\section{Poornima R}

$\mathrm{Ph}$. D Scholar, University of

Agricultural Sciences, Dharwad, Karnataka, India

\section{Koti RV}

Professor, Department of Crop Physiology, University of Agricultural Sciences, Dharwad, Karnataka, India

Corresponding Author: Poornima R

Ph. D Scholar, University of Agricultural Sciences, Dharwad, Karnataka, India

\title{
Influence of zinc oxide nano particle on biophysical parameters, yield and grain zinc content of rabi sorghum (Sorghum bicolor)
}

\section{Poornima R and Koti RV}

DOI: https://doi.org/10.22271/chemi.2020.v8.i2aj.9109

\begin{abstract}
A pot experiment was conducted to find out the influence of zinc oxide nano particle on photosynthesis, shoot and root growth and yield in rabi sorghum (Sorghum bicolor var M-35-1) at Department of Crop Physiology, UAS, Dharwad, Karnataka. Experiment consisted of twelve treatments comprised of seed priming (200, 500 and $1000 \mathrm{ppm}$ of nano $\mathrm{ZnO}$ and bulk $\left.\mathrm{ZnSO}_{4}\right)$, foliar application (200, 500, 1000, and $1500 \mathrm{ppm}$ of nano $\mathrm{Zno}$ ) and $1000 \mathrm{ppm}$ of $\mathrm{ZnSO}_{4}$ (package of practice) with six replications was carried out. Nano $\mathrm{ZnO} 500 \mathrm{ppm}$ of foliar spray recorded significantly higher shoot length (186.67), shoot dry weight (108.6), root length (83.33), root volume (310) and root dry weight (57.23) as compared to 1000 ppm bulk $\mathrm{ZnSO}_{4}$. Nano $\mathrm{ZnO} 500 \mathrm{ppm}$ foliar spray recorded significantly higher chlorophyll content (1.39), SPAD values (49.57), photosynthetic rate (41.23), transpiration rate (0.19) and stomatal

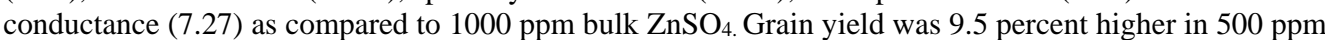
of NFS and $1000 \mathrm{ppm}$ NFS as compared to $1000 \mathrm{ppm}$ of BFS. The gain zinc content was $5.6 \%$ higher in $500 \mathrm{ppm}$ of NFS as compare with 1000 ppm of BFS. Compared to control both nano $\mathrm{ZnO}(18 \%)$ and Bulk ZnSO4 (11\%) have higher zinc accumulation in their grains. The inhibitory effect was observed in nano $\mathrm{ZnO}$ concentration $>1000 \mathrm{ppm}$ reveals the toxicity and need for judicious usage of nano particles in foliar applications. This is the first report on the effect of nano $\mathrm{ZnO}$ particles on sorghum growth, photosynthesis, grain yield and zinc content.
\end{abstract}

Keywords: Nano particles, zinc oxide, sorghum, seed priming, foliar application

\section{Introduction}

Among abiotic stresses nutritional stress is the third most important stress limiting plant productivity. Among different nutrients, $\mathrm{Zn}$ is considered as the fourth most important yieldlimiting nutrient after nitrogen $(\mathrm{N})$, phosphorus $(\mathrm{P})$ and potassium $(\mathrm{K})$. The major challenge for global food and nutrition security is to feed the increasing world population with nutritious food. Therefore in the future, it is essential to increase not only production but also of high quality food with the required level of nutrients and protein is the main challenge. Therefore the zinc content in grains, such as rice, wheat and sorghum is of major importance which is consumed in bulk worldwide and Karnataka (Anand et al., 2008) ${ }^{[2]}$. Indian soils are deficient in zinc and food crops grown on these soils and human beings living in this area are suffering from zinc deficiency. Sorghum is a major cereal grown in Maharashtra and Northern Karnataka and bulk of the food consumed by the people in these regions contains sorghum. To overcome this nutritional problem and crop production, conventionally bulk form of $\mathrm{ZnSO}_{4}$ is applied to soil or to foliage as exogenous source, but most of the time the bulk forms are going to be fixed in the soil and making it non-available to the rhizosphere and becomes toxic to the soil microorganisms and plants. Recently, nanotechnology is coming into focus because nano particles (NPs) are small in size $(<100 \mathrm{~nm})$ having high surface area and reactivity. Recent studies revealed that powder or nano sized particles are found to be effective in absorption and translocation. But, physiological aspects of nano zinc application and its accumulation in grains crops are meagre. Hence, the present study was carried out to investigate the effects of various concentrations of Zinc Oxide ( $\mathrm{ZnO})$ NPs on growth, yield and grain $\mathrm{Zn}$ content in rabi sorghum (Sorghum bicolor) var M-35-1. 


\section{Material and Methods}

A pot (White Plastic bags) experiment was carried out in sorghum var M-35-1 rabi 2015 at Department of Crop Physiology, UAS, Dharwad. The bags were filled with calcareous soil. Zinc oxide nano particle ( $\mathrm{ZnO}$ NPs) with average particle size (APS) of $\approx 30 \mathrm{~nm}$ and bulk $\mathrm{ZnSO}_{4} 7 \mathrm{H}_{2} \mathrm{O}$ were used in the experiment as source of nano and bulk form of zinc respectively (Plate 1).

\section{Preparation of particle suspensions for seed priming and foliar treatment}

Required concentration of $\mathrm{ZnO}$ nano particle was suspended directly in deionised water and dispersed by ultrasonic vibration $(100 \mathrm{~W}, 40 \mathrm{KHz})$ for $30 \mathrm{~min}$. Magnetic bars were placed in the suspensions for stirring before use to avoid aggregation of the particles. The nano scale suspensions as expected appeared as clear solutions. The $\mathrm{pH}$ of all the suspensions were measured and adjusted to 6.8. Bulk $\mathrm{ZnSO}_{4}$ was used as a reference $\mathrm{Zn}$ source and it dissolves easily in water.

\section{Seed priming and foliar application of nano $\mathrm{ZnO}$ and bulk $\mathrm{ZnSO}_{4}$}

The bulk $\mathrm{ZnSO}_{4}$ solution and nano $\mathrm{ZnO}$ suspensions were prepared with concentrations of 200, 500, $1000 \mathrm{ppm}$ (concentrations in terms of $\mathrm{Zn}$ content). Seeds were soaked in $100 \mathrm{ml}$ of these solution of bulk $\mathrm{ZnSO}_{4}$ (bulk seed priming: BSP) and suspensions of nano $\mathrm{ZnO}$ (nano seed priming: NSP) for six hours and shade dried till it reaches initial weight. Simultaneously, two sets of seeds were soaked in water and shade dried for foliar treatments (200, 500, 1000 and 1500 ppm of nano $\mathrm{ZnO}$ and 1000 ppm bulk $\mathrm{ZnSO}_{4}$ ) along with control (without zinc). For each treatment six replications were maintained. Both nano $\mathrm{ZnO}$ foliar spray (NFS) and bulk $\mathrm{ZnSO}_{4}$ foliar spray (BFS) were carried out at 35 and 75 days after sowing. The morphological parameters like shoot length, shoot dry weight, root length, root volume, root dry weight and shoot chlorophyll content, SPAD values, Photosynthetic rate, transpiration rate and stomatal conductance are measured at 85 DAS. Grain yield and grain zinc content was recorded at harvest. For data analysis the level of significance used in ' $F$ ' and ' $\mathrm{t}$ ' test was $\mathrm{P}=0.01$. The least significant differences (LSD) values were calculated wherever the ' $F$ ' test was significant by Duncan's Multiple Range Test (DMRT).

\section{Results and Discussion}

In the present experiment application of nano zinc oxide as foliar spray recorded significantly higher chlorophyll content, SPAD values, Photosynthetic rate, transpiration rate, stomatal conductance, shoot length, shoot dry weight, root length, root volume, root dry weight, grain yield and grain zinc content as compared to bulk $\mathrm{ZnSO}_{4}$ application.

\section{Influence of zinc oxide nano particles on chlorophyll content and photosynthesis}

The leaf chlorophyll content is often used as an indicator of plant growth for evaluating assimilation and vigour and is also a major factor determining the solar radiation interception, canopy photosynthesis. All the essential mineral nutrients directly or indirectly have role to play in photosynthetic process. Zinc is one among them, proved that external supply would bring about changes in physiology and growth of plants (Anand et al., 2008 in sorghum; Dore et al., 2016 in rice ; Raghavendra et al., 2015 in wheat) ${ }^{[2,8,17]}$. In the experiment nano zinc oxide is adopted because of its unique properties like small size and high reactivity as compared to bulk $\mathrm{ZnSO}_{4}$

Nano $\mathrm{ZnO}$ at concentration of $500 \mathrm{ppm}$ NFS and followed by $1000 \mathrm{ppm}$ NFS proved to be optimum and effective in improving chlorophyll content (1.39 and 1.28 ), SPAD values (49.57 and 47.23), Photosynthetic rate (41.23 and 40.97), Transpiration rate $(0.19$ and 0.18$)$ and stomatal conductance (7.27 and 6.93) as compared to $1000 \mathrm{ppm}$ BFS and control (Table 1) respectively. Similar results were reported by Zayed et al. (2011) ${ }^{[24]}$ and Sarwar et al. (2013) ${ }^{[20]}$ in rice crop but no reports are available in sorghum.

Plants treated with nano $\mathrm{ZnO}$ had significantly higher chlorophyll content than the bulk Zn. Zinc is known to have primary role in leaf photosynthesis and may probably keep up chlorophyll synthesis through sulphydryl bunch protection (Cakmak 2000) [6] and plays major role in chlorophyll synthesis and activation of some proteins (Broadley et al., 2007) ${ }^{[4]}$. Earlier works also confirm that zinc application improves chlorophyll content (Chaab et al., 2011; Weisany et al., 2014; Koti et al., 2009 and Gurmani et al., 2012) [7, 23,12]. Taiz and Zeiger (2010) ${ }^{[21]}$ reported that many enzymes require $\mathrm{Zn}^{+2}$ ion for their activity, and $\mathrm{Zn}$ may be required for chlorophyll biosynthesis in plants. Besides that, $\mathrm{Zn}$ plays a key role in photosynthesis, affecting the activity of enzymes such as carbonic anhydrase (Rengel, 1995a) ${ }^{[19]}$, as well as affecting chlorophyll concentration and stomatal conductance (Hu and Sparks, 1991). In this context, Bergmann (1992) ${ }^{[3]}$ reported that $\mathrm{Zn}$ is believed to be involved in chlorophyll synthesis through its influence on protein, carbohydrate, and energy metabolism. Supportive to the present work, bioengineered nano $\mathrm{ZnO}$ in cotton increased the rate of photosynthetic pigments significantly even at higher doses, and this might be due to the presence of phyto molecule ligands on the nano $\mathrm{ZnO}$ and level of total soluble protein (Priyanka and Venkatachalam, 2016) ${ }^{[16]}$. Results of Adhikari et al. (2015) indicated that seed coating of maize, soybean, pigeon pea and ladies finger with micron and nano scale zinc through different sources increased the total chlorophyll content in the leaves and IAA production by root and subsequently increases the overall growth of the plant.

\section{Influence of zinc oxide nano particles on shoot and root growth}

Root is the most important and deciding plant part for uptake of water and nutrients from soil and translocation to the above ground parts, similarly shoot is the deciding part of the plant in assimilation and photosynthesis leading to crop growth and yield. Results revealed that nano $\mathrm{ZnO}$ at concentration of 500 ppm proved to be optimum and effective in improving shoot length (186.67), shoot dry weight (108.60) root length (83.33), root dry weight (57.23), root volume (310), grain yield (63) and grain zinc content (19.73) respectively as compared to $1000 \mathrm{ppm}$ of bulk $\mathrm{ZnSO}_{4}$ and control (Table 2 and Plate 2).

Although the root to shoot ratios are the main indicators of physiological processes affecting growth and yield of the crop, root to shoot ratio helps in understanding the division of photosynthates and nutrients to above and below ground parts and helps to know the source to sink ratio (Upadhyaya et al., $2015)^{[22]}$. Zinc acts as an activator of enzymes in plants and is directly involved in the biosynthesis of auxin, which produces more cells and leads to high shoot and root growth in studies of Rahman et al. (2001) ${ }^{[18]}$ and Nathan et al. (2001) ${ }^{[15]}$ in rice, Genc et al. (2006) ${ }^{[10]}$ and Faruk et al. (2006) ${ }^{[9]}$ in bread wheat, Probable reason might be due to favourable effect of 
zinc on the proliferation of roots and thereby increasing the uptake of other plant nutrients from the soil, supplying it to the aerial parts of the plant and helps in enhancing the vegetative growth and reproductive growth of plants

Similar results were obtained by Burmana et al. (2013) ${ }^{[5]}$ and Mahajan et al. (2011) ${ }^{[14]}$ in chickpea seedling supplied with nano ZnO. Similarly, Laware and Raskar, 2014 also reported significant increase in root growth and dry weight in case of onion after zinc oxide nano-particles application. Higher uptake of other mineral nutrients are also known to increase the demand of $\mathrm{Zn}$ and also by the complementary effect of other inherent nutrients like magnesium, iron and sulphur (Koti et al., 2009) ${ }^{[12]}$. The results revealed that nano zinc oxide particle application has promontory effect at optimum concentration but has inhibitory/toxic effects at higher concentration on root and shoot growth. Lower doses of nano
$\mathrm{ZnO}$ is sufficient to achieve positive response and higher doses showed growth retardation.

Nano $\mathrm{ZnO}$ foliar application at the half (500 ppm NFS) or equal (1000 ppm NFS) concentration when compared to its counter bulk $\mathrm{ZnSO}_{4}$ (1000 ppm BFS) has significantly increased the growth and photosynthesis in sorghum. Positive improvement in NFS might be due to the quick translocation and assimilation of $\mathrm{Zn}$ nanoparticles which further leading to the expression of growth accelerating enzymatic activity and auxin metabolism in plants. The probable reasons for inefficiency of bulk $\mathrm{ZnSO}_{4}$ are its high solubility and low retention time in the plant system. So the bioavailability/ sustainable availability of bulk particle inside the plant system and also at the site of uptake are not confirmed. But as an advantage over bulk nano $\mathrm{ZnO}$ is quickly absorbed by leaf surface and also metabolized faster than bulk form because of its nano sized particles.

Table 1: Effect of nano $\mathrm{ZnO}$ and bulk $\mathrm{ZnSO}_{4}$ application on chlorophyll content, SPAD values, photosynthetic rate, transpiration rate and stomatal conductance in sorghum at 85 DAS.

\begin{tabular}{|c|c|c|c|c|c|}
\hline Treatments & $\begin{array}{c}\text { Total Chl content } \\
\left(\mathrm{mg} \mathrm{g}^{-1} \text { fr.wt. }\right)\end{array}$ & SPAD values & $\begin{array}{c}\text { Photosynthetic rate } \\
\left(\mu \mathrm{mole} \text { of } \mathrm{CO}_{2} \mathrm{~m}^{-2} \mathrm{sec}^{-1}\right)\end{array}$ & $\begin{array}{c}\text { Transpiration rate } \\
\left(\mathrm{mmoles}^{-} \mathrm{H}_{2} \mathrm{O} \mathbf{~ m}^{-2} \mathrm{sec}^{1}\right)\end{array}$ & $\begin{array}{l}\text { Stomatal conductance } \\
\left(\mu \mathrm{mol} \mathrm{H}_{2} \mathrm{O} \mathbf{~ m}^{-2} \mathbf{s e c}^{-1}\right)\end{array}$ \\
\hline 200 ppm BSP & $0.51^{\mathrm{de}}$ & $46.03^{\mathrm{a}-\mathrm{c}}$ & $32.63^{\mathrm{c}}$ & $0.15^{\mathrm{b}-\mathrm{e}}$ & $5.20^{\mathrm{c}-\mathrm{e}}$ \\
\hline 500 ppm BSP & $0.55^{\mathrm{de}}$ & $46.80^{\mathrm{ab}}$ & $35.53^{\mathrm{b}}$ & $0.17^{\mathrm{a}-\mathrm{c}}$ & $5.74^{\mathrm{b}-\mathrm{d}}$ \\
\hline 1000 ppm BSP & $0.55^{\mathrm{de}}$ & $46.83^{\mathrm{ab}}$ & $38.50^{\mathrm{a}}$ & $0.18^{\mathrm{ab}}$ & $6.25^{\mathrm{a}-\mathrm{c}}$ \\
\hline 200 ppm NSP & $0.47^{\mathrm{e}}$ & $42.83^{\mathrm{bc}}$ & $31.40^{\text {cd }}$ & $0.12^{\mathrm{ef}}$ & $4.80^{\mathrm{de}}$ \\
\hline $500 \mathrm{ppm}$ NSP & $0.57^{\mathrm{de}}$ & $45.03^{\mathrm{a}-\mathrm{c}}$ & $32.27^{\mathrm{cd}}$ & $0.14^{\mathrm{c}-\mathrm{f}}$ & $5.17^{\mathrm{c}-\mathrm{e}}$ \\
\hline 1000 ppm NSP & $0.74^{\mathrm{c}}$ & $43.57^{\mathrm{a}-\mathrm{c}}$ & $32.07^{\mathrm{cd}}$ & $0.13^{\mathrm{d}-\mathrm{f}}$ & $5.14^{\mathrm{c}-\mathrm{e}}$ \\
\hline 200 ppm NFS & $0.57^{\mathrm{de}}$ & $46.07^{\mathrm{a}-\mathrm{c}}$ & $33.47^{\mathrm{bc}}$ & $0.16^{\mathrm{a}-\mathrm{d}}$ & $5.29^{\mathrm{c}-\mathrm{e}}$ \\
\hline $500 \mathrm{ppm}$ NFS & $1.39^{\mathrm{a}}$ & $49.57^{\mathrm{a}}$ & $41.23^{\mathrm{a}}$ & $0.19^{\mathrm{a}}$ & $7.27^{\mathrm{a}}$ \\
\hline 1000 ppm NFS & $1.28^{\mathrm{a}}$ & $47.23^{\mathrm{ab}}$ & $40.97^{\mathrm{a}}$ & $0.18^{\mathrm{ab}}$ & $6.93^{\mathrm{a}}$ \\
\hline 1500 ppm NFS & $0.74^{\mathrm{c}}$ & $46.97^{\mathrm{ab}}$ & $39.40^{\mathrm{a}}$ & $0.18^{\mathrm{ab}}$ & $6.47^{\mathrm{ab}}$ \\
\hline 1000 ppm BFS & $0.90^{\mathrm{b}}$ & $47.50^{\mathrm{ab}}$ & $41.17^{\mathrm{a}}$ & $0.18^{\mathrm{ab}}$ & $7.11^{\mathrm{a}}$ \\
\hline Control & $0.64^{\text {cd }}$ & $40.40^{c}$ & $29.77^{\mathrm{d}}$ & $0.11^{\mathrm{f}}$ & $4.40^{\mathrm{e}}$ \\
\hline S.Em.t & 0.03 & 1.31 & 0.64 & 0.01 & 0.26 \\
\hline LSD @ $1 \%$ & 0.12 & 5.24 & 2.55 & 0.03 & 1.03 \\
\hline
\end{tabular}

BSP-Bulk Zn Seed priming, NSP-Nano Zn Seed priming, NFS-Nano Zn Foliar Spray, BFS-Bulk Zn Foliar Spray

Table 2: Effect of nano $\mathrm{ZnO}$ and bulk $\mathrm{ZnSO}_{4}$ application on shoot length, shoot dry weight, root length, root volume, root dry weight, grain yield and grain zinc in sorghum.

\begin{tabular}{|c|c|c|c|c|c|c|c|}
\hline Treatment & $\begin{array}{c}\text { Shoot length } \\
\left(\mathrm{cm} \text { plant }^{-1}\right)\end{array}$ & $\begin{array}{c}\text { Shoot dry weight } \\
\left(\text { g plant }^{-1}\right)\end{array}$ & $\begin{array}{l}\text { Root length } \\
\left(\mathrm{cm} \text { plant }^{-1}\right)\end{array}$ & Root volume $\left(\mathrm{cm}^{3}\right)$ & $\begin{array}{c}\text { Root dry weight } \\
\left(\text { g plant }^{-1}\right)\end{array}$ & $\begin{array}{c}\text { Grain yield } \\
\left(\text { g plant }^{-1}\right)\end{array}$ & $\begin{array}{c}\text { Grain } \\
\text { Zinc (ppm) } \\
\end{array}$ \\
\hline $200 \mathrm{ppm}$ BSP & $164.67^{\mathrm{a}}$ & $66.07^{\mathrm{ef}}$ & $67.33^{\text {cd }}$ & $142.33^{\mathrm{fg}}$ & $40.10^{\mathrm{c}}$ & $52.4^{\mathrm{bc}}$ & $14.40^{\mathrm{bc}}$ \\
\hline 500 ppm BSP & $171.00^{\mathrm{a}}$ & $76.30^{\mathrm{a}}$ & $73.00^{\mathrm{bc}}$ & $163.33^{\mathrm{e}-\mathrm{g}}$ & $44.67^{b}$ & $52.9^{\mathrm{bc}}$ & $16.58^{\mathrm{a}-\mathrm{c}}$ \\
\hline 1000 ppm BSP & $174.00^{\mathrm{a}}$ & $80.50^{\mathrm{a}}$ & $73.67^{\mathrm{b}}$ & $213.67^{\mathrm{c}-\mathrm{e}}$ & $45.17^{\mathrm{b}}$ & $53.8^{\mathrm{a}-\mathrm{c}}$ & $13.75^{\mathrm{c}}$ \\
\hline $200 \mathrm{ppm}$ NSP & $128.67^{\mathrm{b}}$ & $58.03^{\mathrm{g}}$ & $65.00^{\mathrm{d}}$ & $230.00^{\mathrm{b}-\mathrm{d}}$ & $31.27^{\mathrm{de}}$ & $46.4^{\mathrm{c}}$ & $15.63^{\mathrm{a}-\mathrm{c}}$ \\
\hline 500 ppm NSP & $164.33^{\mathrm{a}}$ & $63.40^{\mathrm{ef}}$ & $67.33^{\text {ad }}$ & $240.00^{b-d}$ & $38.07^{\mathrm{c}}$ & $49.8^{\mathrm{bc}}$ & $17.60^{\mathrm{a}-\mathrm{c}}$ \\
\hline 1000 ppm NSP & $163.00^{\mathrm{a}}$ & $61.23^{\mathrm{fg}}$ & $66.33^{\mathrm{d}}$ & $246.67^{\mathrm{bc}}$ & $32.07^{\mathrm{d}}$ & $48.1^{\mathrm{bc}}$ & $18.40^{\mathrm{ab}}$ \\
\hline 200 ppm NFS & $166.00^{\mathrm{a}}$ & $68.00^{\mathrm{e}}$ & $72.67^{\mathrm{bc}}$ & $273.00^{\mathrm{ab}}$ & $40.70^{c}$ & $51.7^{\mathrm{bc}}$ & $16.88^{\mathrm{a}-\mathrm{c}}$ \\
\hline 500 ppm NFS & $186.67^{\mathrm{a}}$ & $108.60^{\mathrm{a}}$ & $83.33^{\mathrm{a}}$ & $310.00^{\mathrm{a}}$ & $57.23^{\mathrm{a}}$ & $63.0^{\mathrm{a}}$ & $19.73^{\mathrm{a}}$ \\
\hline 1000 ppm NFS & $185.00^{\mathrm{a}}$ & $91.20^{c}$ & $80.00^{\mathrm{a}}$ & $285.00^{\mathrm{ab}}$ & $46.33^{b}$ & $55.1^{\mathrm{a}-\mathrm{c}}$ & $16.15^{\mathrm{a}-\mathrm{c}}$ \\
\hline $1500 \mathrm{ppm}$ NFS & $175.00^{\mathrm{a}}$ & $80.57^{\mathrm{d}}$ & $78.00^{\mathrm{ab}}$ & $250.00^{\mathrm{bc}}$ & $45.67^{\mathrm{b}}$ & $55.2^{\mathrm{a}-\mathrm{c}}$ & $16.35^{\mathrm{a}-\mathrm{c}}$ \\
\hline 1000 ppm BFS & $185.00^{\mathrm{a}}$ & $102.87^{\mathrm{b}}$ & $81.00^{\mathrm{a}}$ & $291.67^{\mathrm{ab}}$ & $46.40^{\mathrm{b}}$ & $57.5^{\mathrm{ab}}$ & $18.68^{\mathrm{a}}$ \\
\hline Control & $112.33^{\mathrm{b}}$ & $51.33^{\mathrm{h}}$ & $62.00^{\mathrm{d}}$ & $133.33^{\mathrm{g}}$ & $28.00^{\mathrm{e}}$ & $46.2^{\mathrm{c}}$ & $16.6^{\mathrm{a}-\mathrm{c}}$ \\
\hline S.Em.土 & 7.1 & 1.17 & 1.44 & 12.6 & 0.97 & 2.21 & 0.93 \\
\hline LSD @ 1\% & 28.31 & 4.66 & 5.72 & 50.22 & 3.88 & 8.81 & 3.72 \\
\hline
\end{tabular}

BSP-Bulk Zn Seed priming, NSP-Nano Zn Seed priming, NFS-Nano Zn Foliar Spray, BFS-Bulk Zn Foliar Spray 


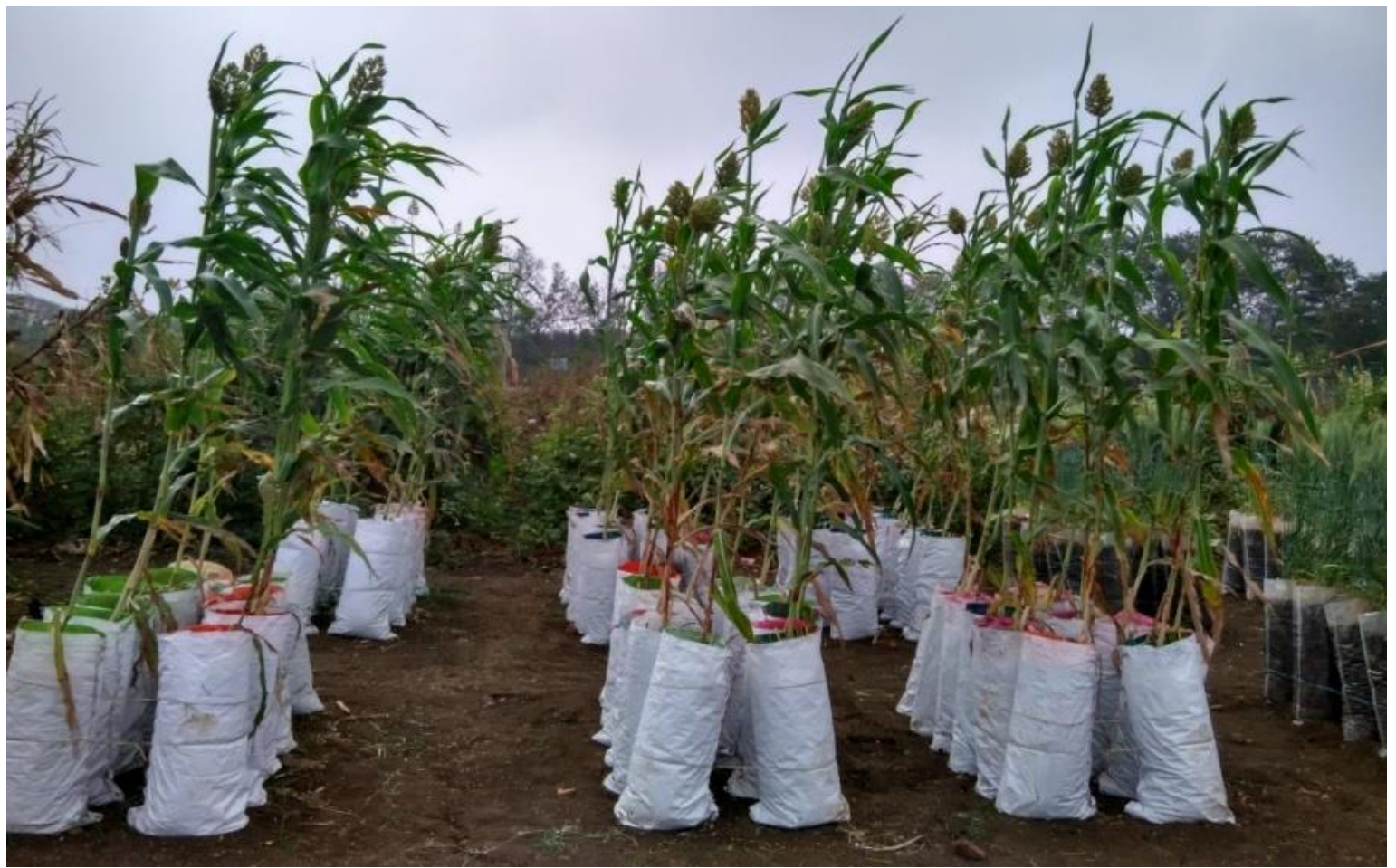

Plate 1: General view of sorghum experiment treated with different concentrations of nano $\mathrm{ZnO}$ and bulk $\mathrm{ZnSO}_{4}$
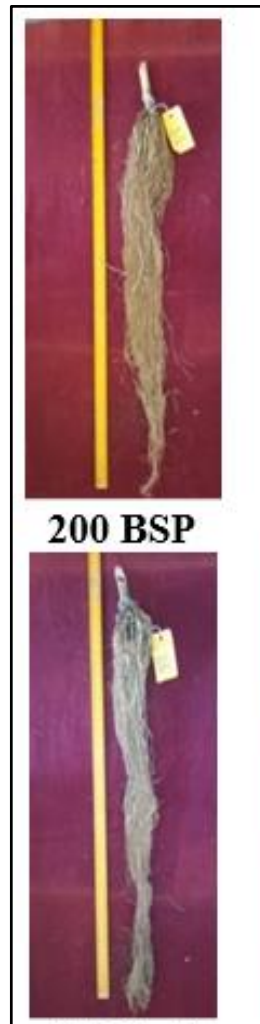

200 NFS

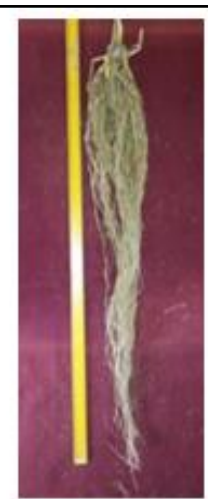

500 BSP

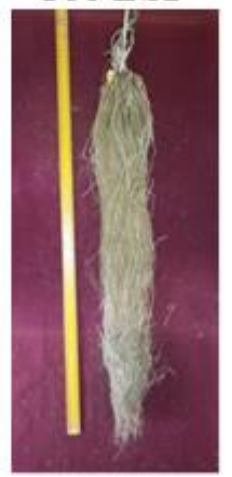

500 NFS
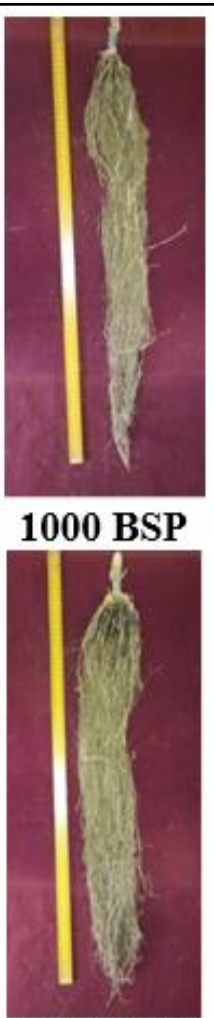

1000 NFS

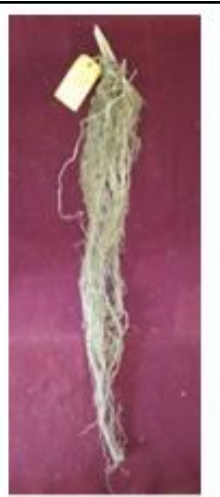

200 NSP

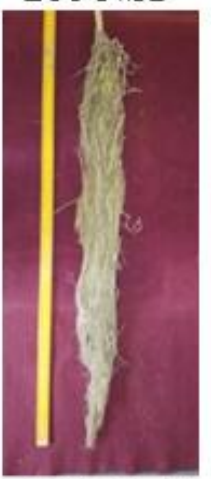

1500 NFS
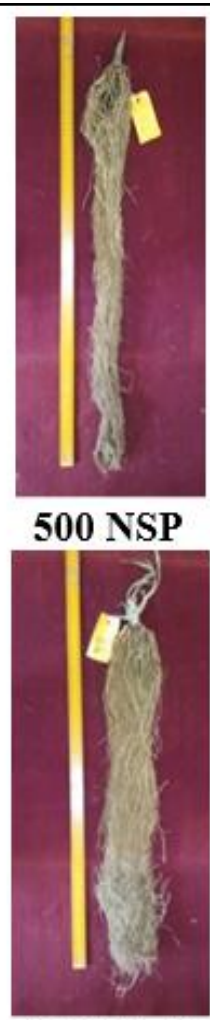

$1000 \mathrm{BFS}$

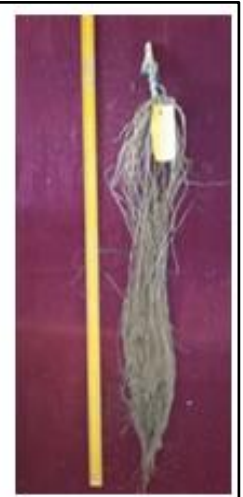

1000 NSP

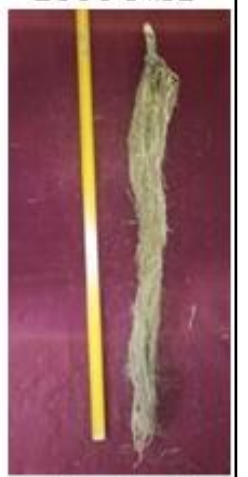

Control

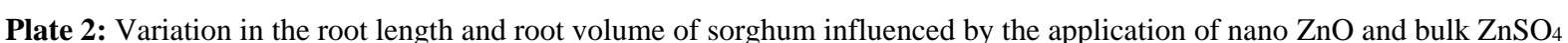

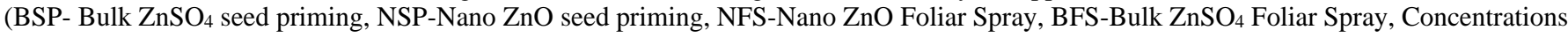
are in $\mathrm{ppm}$ )

\section{Conclusion}

The study shows that application of nano $\mathrm{ZnO}$ recorded more photosynthetic rate, shoot, root growth, grain yield and grain zinc content of sorghum as compare to bulk $\mathrm{ZnSO}_{4}$. Application of nano $\mathrm{ZnO}$ formulations may reduce the high doses of bulk fertilizers, wastage of fertilizers, environmental hazards and increase nutrient use efficiency. There is a need to standardize the optimum nano fertilizer dose for different crop and optimum stage of application to the crop to achieve better crop production. Need to understand intra and extra cellular mechanisms involved in uptake and translocation of nano particles. In conclusion, foliar fertilization of $500 \mathrm{ppm}$ NFS was found more effective than 1000 ppm BFS. In conclusion, the nano $\mathrm{ZnO}$ application through foliar spray is effective to obtain the desired crop growth, yield and grain zinc content at much lower doses than bulk $\mathrm{ZnSO}_{4}$. 


\section{References}

1. Adhikari T, Kundu S, Biswas AK, Tarafdar JC, Rao S. S. Zinc delivery to plants through seed coating with nanozinc oxide particles. J Pl. Nutr. 2016a; 39(1):136-146.

2. Anand R, Koti RV, Kamatar MY, Mummigatti UV, Basavaraj B. Evaluation of rabi sorghum genotypes for seed zinc content and yield in high regimes. Karnataka. J Agric. Sci. 2008; 21(4):568-569.

3. Bergmann W. Nutritional Disorders of Plants: Developments, Visual and Analytical Diagnosis. Agricultural Sciences, September 23, 2014, methods of soil analysis Part 2, Second Edition, Gustav Fischer Verlang Jena, New York, 1992; 5:11.

4. Broadley MR, Philip JW, Hammond JP, Zelko I, Lux A. Zinc in plants, New Phytologist. 2007; 73(4):677-702.

5. Burmana U, Saini M, Kumar P. Effect of zinc oxide nanoparticles on growth and antioxidant system of chickpea seedlings. Toxicol. Environ. Chem. 2013; 95(4):605-612.

6. Cakmak I. Tansley review number 111: possible roles of zinc in protecting plant cells from damage by reactive oxygen species. New Phytologist. 2000; 146(2):185-205.

7. Chaab A, GH, Savaghebi R, Motesharezadeh B. Differences in the zinc efficiency among and with in maizecultivars in a calcareous soil. Asian J Agric. Sci., 2011; 3(1):26-31.

8. Dore V, Koti RV. Effect of zinc application on morphological, Zinc content and grain yield of rice genotypes, Advances in life sciences, 2016; 5(18):74087413, ISSN 2278-3849.

9. Faruk O, Bulent T, Cakmak I. Effect of zinc flumate on growth of soybean and wheat in zinc deficient communication. Soil Sci. Pl. Ann. 2006; 137:2769-2778.

10. Genc Y, McDonald GK, Graham RD. Contribution of different mechanism to zinc efficiency in bread wheat during early vegetative stage. Pl. Soil. 2006; 281(1, 2):353-367

11. Gurmani AR, Din JU, Khan SU, Andaleep R, Waseem K, Khan A et al. Soil application of zinc improves growth and yield of tomato. Int. J Agric. Biol. 2012; 14:91-96.

12. Koti RV, Mummigatti UV, Nawalgatti CM, Savita FH, Guled MB, Anand A. Complimenatry effect of zinc application on iron content in sorghum genotypes. Indian J Plant Physilol., 2009; 14(1):78-81.

13. Laware SL, Raskar S. Influence of zinc oxide nanoparticles on growth, flowering and seed productivity in onion. International J Curr. Microbiol. App. Sci., 2014; 3(7):874-881

14. Mahajan P, Dhoke SK, Khanna AS. Effect of Nano-ZnO Particle Suspension on Growth of Mung (Vigna radiata) and Gram (Cicer arietinum) Seedlings using plant agar method. J Nanotechnol. 2011; 696535:1-7.

15. Nathan A, Slaton CE, Wilson JR, Sixte N, Richard JN, Danny LB. Evaluation of zinc seed treatments for rice. Agron. J. 2001; 93:152-157.

16. Priyanka N, Venkatachalam P. Biofabricated zinc oxide nanoparticles coated with phycomolecules as novel micronutrient catalysts for stimulating plant growth of cotton, Adv. Nat. Sci.: Nanosci. Nanotechnol. 2016; 7:111.

17. Raghavendra TR, Koti RV, Patil BN. Influence of zinc application on growth parameters, grain yield and zinc content in bread wheat (Triticum aestivum L.,) Karnataka journal of Agric. Sci. 2015; 28(3): 409-411.
18. Rahman A, Yassen M, Akram M, Awan ZI. Response of rice to zinc application and different sources in calcareous soil. Pakistan J Biol. Sci., 2001; 4:285-287.

19. Rengel Z, Graham RD. Wheat genotypes differ in Zn efficiency when grown in chelate-buffered nutrient solution: II. Nutrient uptake. Pl. Soil. 1995a; 176:317324.

20. Sarwar N, Ali A, Ahmad E, Ullah S, Ahmad K, Mubeen, Hill JE. Water wise rice cultivation on calcareous soil with the addition of essential micronutrients. J Anim. Plant Sci., 2013; 23(10):244-250.

21. Taiz L, Zeiger E. Plant physiology, $5^{\text {th }}$ edn. Sinauer Associates Inc., Massachusetts, 2010, 781.

22. Upadhyaya HS, Shome ST, Bhattacharya MK, Panda SK. Effect of Zn Nano-Particles on Growth Responses of Rice., Nanotechnology: novel perspectives and prospects; e-book published by Mc Graw Hill Publication Private Limited, 2015, 508-512.

23. Weisany W, Sohrabi Y, Heidari G, Siosemardeh A. Effects of zinc application on growth, absorption and distribution of mineral nutrients under salinity stress in soybean (Glycine max L.). J Pl. Nutr. 2014; 37(14):22552269.

24. Zayed BA, Salem AKM, Sharkawy HME. Effect of different micronutrient treatments on rice (Oriza sativa L.) growth and yield under saline soil conditions. World $\mathbf{J}$ Agric. Sci., 2011; 7(2):179-184. 